\title{
Analisis Kualitas Kascing dari Campuran Kotoran Sapi, Pelepah Kelapa Sawit dan Limbah Sayuran
}

\author{
Siti Afsyah, Hilwa Walida*, Kamsia Dorliana, Yusmaidar Sepriani, Fitra Syawal Harahap \\ Prodi Agroteknologi, Fakultas Sains dan Teknologi, Universitas Labuhanbatu \\ Email co-author* : hw2191@gmail.com
}

\begin{abstract}
Abstrak
Bidang perkebunan kelapa sawit dan peternakan merupakan salah satu sektor utama di Kabupaten Labuhanbatu, Sumatera Utara.Tingginya produksi kelapa sawit dan jumlah ternak tentunya diikuti dengan besarnya jumlah limbah yang dihasilkan pertahunnya. Pelepah kelapa sawit dan kotoran sapi mengandung bahan organik yang cukup banyak dan sayang bila tidak dimanfaatkan. Penelitian ini menggunakan limbah pelepah sawit, kotoran sapi dan limbah sayuran sebagai pakan dan media untuk budidaya cacing tanah, hingga didapatkan kascing yang dapat digunakan sebagai pupuk organik. Penelitian ini bertujuan untuk mengetahui kandungan $\mathrm{N}, \mathrm{P}, \mathrm{K}, \mathrm{C}$ organik dan pH pada pupuk kascing yang dihasilkan. Penelitian ini dilakukan dengan membudidayakan cacing tanah yang diberi pakan $1 \mathrm{~kg}$ kotoran sapi yang telah diencerkan dengan air 1 liter ditambah limbah sayuran sebanyak 500 gr. Hasil penelitian selanjutnya dianalisis secara deskriptif dengan membandingkan hasil penelitian dengan kompos standart SNI-19-7030-2004. Hasil uji menunjukkan bahwa kascing ini mengandung C-Org sebesar 10,55\%, N sebesar 1,07\%, P sebesar 0,22\%, K sebesar 0,30\%, C/N sebesar 9,85 dan pH sebesar 6,5. Dengan demikian, kascing tersebut memenuhi standart SNI-19-7030-2004 sebagai kompos.
\end{abstract}

Kata Kunci: Kotoran Sapi; Pelepah Sawit; Limbah Sayuran; Kascing

\begin{abstract}
Oil palm plantations and livestock are one of the main sectors in Labuhanbatu Regency, North Sumatra. The high production of oil palm and the number of livestock is of course followed by the large amount of waste produced annually. Oil palm midribs and manure contain a lot of organic material which is a shame if not used. This research used palm midribs, manure and vegetable waste as feed and media for cultivating earthworms, so that vermicompost can be used as organic fertilizer. This study aims to determine the content of organic $N, P, K, C$ and $p H$ in the vermicompost fertilizer. This research was conducted by cultivating earthworms that were fed $1 \mathrm{~kg}$ of manure which has been diluted with 1 liter of water and $500 \mathrm{gr}$ of vegetable waste. The results of the research were further analyzed descriptively by comparing the results of the study with the compost standard SNI-19-7030-2004. The test results showed that this vermicompost contained $10.55 \%$ C-Org, $1.07 \%$ N, 0.22\% P, 0.30\% K, $9.85 \mathrm{C} / \mathrm{N}$ and a pH of 6.5. Thus, the vermicompost fulfills the SNI-19-7030-2004 standard as compost.
\end{abstract}

Keywords: Manure; Oil Palm Midrib; Vegetable Waste; Vermicompost

\section{Pendahuluan}

Bidang perkebunan kelapa sawit dan peternakan merupakan salah satu sektor utama di Kabupaten Labuhanbatu, Sumatera Utara.Berdasarkan data (BPS Kabupaten Labuhanbatu (2016), luas lahan perkebunan sawit rakyat mencapai 38.206,40 hektar dan produksinya sebesar 91.514 ton, sedangkan jumlah sapi potong tercatat sebanyak 19.604 ekor, kerbau 174 ekor, dan kambing 15.075 ekor.Tingginya produksi kelapa sawit dan jumlah ternak tersebut tentunya diikuti dengan besarnya jumlah limbah yang dihasilkan pertahunnya.

Pelepah kelapa sawit merupakan limbah padat yang dihasilkan sepanjang tahun oleh perkebunan kelapa sawit. Satu hektar kelapa sawit menghasilkan pelepah daun dengan bobot kering sebanyak 14,47 ton sekali dalam 30 tahun (peremajaan) dan 10,40 ton dari pangkasan setahun (Ditjen PPHP, 2006). Hewan ternak juga tentunya menghasilkan limbah, dimana dalam satu hari setiap ekor sapi dapat menghasilkan limbah padat sebanyak 20-30 kg dan limbah cair sebanyak 100-150 liter (Saputro, 2014).Tingginya jumlah limbah tersebut tanpa adanya pemanfaatan yang baik dari masyarakat tentunya akan menimbulkan permasalahan dalam hal pencemaran lingkungan.

Pelepah kelapa sawit dan kotoran sapi mengandung bahan organik yang cukup banyak dan sayang bila tidak dimanfaatkan. Menurut Ditjen PPHP, (2006) pelepah sawit mengandung $2,38 \%$ nitrogen, $0,157 \%$ fosfat, $1,16 \%$ kalium, $0,287 \%$ magnesium, $0,568 \%$ kalsium, dan daunnya memiliki $0,373 \%$ nitrogen, $0,066 \%$ fosfat, $0,873 \%$ kalium, $0,161 \%$, magnesium, dan 0,295\% kalsium. Begitu juga dengan kotoran sapi yang mengandung bahan organik berupa $0,5 \mathrm{~N}, 0,25 \mathrm{P}_{2}$, $0,5 \% \mathrm{~K}_{2} \mathrm{O}$ dengan kadar air $0,5 \%$, dan juga mengandung unsur mikro esensial lainnya (Parnata, 2010).

Sumber kegiatan yang paling banyak menghasilkan sampah adalah pasar tradisional. Sampah pasar yang banyak mengandung bahan organik adalah sampah sayuran atau sayuran yang sudah tidak dapat digunakan atau dibuang. Limbah sayur memiliki kandungan protein kasar 12,64-23,50 $\%$ dan kandungan serat kasarnya 20,76-29,18\% (Muktiani et al.,2007). Limbah sayuran mendominasi dengan presentasi 
sekitar $70 \%$ perhari. Kadar air yang tinggi membuat berat ratarata jumlah total limbah sayuran yaitu rata-rata 2,96 ton/hari (Febriyantinigrum, 2018).

Mengingat potensi bahan organik yang besar dari limbah-limbah ini, maka dapat dijadikan sebagai salah satu produk kascing. Kascing merupakan pupuk organik yang didapat dari kotoran cacing yang dibudidayakan. Kascing memiliki banyak kandungan unsur hara baik makro dan mikro. Menurut Arifah (2013), pakan yang diberikan kepada cacing akan menentukan jumlah dan kualitas kascing yang dihasilkan. Kualitas dan kuantitas dari makanan merupakan faktor penting dalam pengontrolan biomassa cacing tanah dan jumlah feses yang dihasilkan. Diduga akan terjadi perbedaan kandungan hara dan banyak kascing yang dihasilkan apabila makanan cacing tanah tersebut berbeda. Sehingga penelitian ini akan menggunakan limbah pelepah sawit, kotoran sapi dan limbah sayuran sebagai pakan dan media untuk budidaya cacing tanah, hingga didapatkan kascing yang dapat digunakan sebagai pupuk organik. Untuk mengetahui kualitas dari produk pupuk kascing ini, maka akan dilakukan beberapa uji sehingga diketahui unsur hara yang terkandung di dalamnya.

\section{Metode Penelitian}

Penelitian ini dilaksanakan di Desa Bakaran Batu, Kecamatan Rantau Selatan,Kabupaten Labuhanbatu.Bahanbahan penelitian ini adalah cacing tanah spesies Lumbricus rubeltus, tanah, pelepah kelapa sawit, kotoran sapi. Alat-alat yang digunakan dalam penelitian ini adalah wadah pemeliharaan cacing tanah, rak, timbangan, terpal,paku dan alat lainnya.

Pembuatan kascing dilakukandengan cara memelihara cacing tanah selama 4 minggu. Media budidaya terbuat dari campuran $2 \mathrm{~kg}$ tanah, $1 \mathrm{~kg}$ pelepah kelapa sawit dan $1 \mathrm{~kg}$ bibit cacing tanah ukuran $8 \mathrm{~cm}$. Cacing diberi makan setiap 2-3 hari sekali dengan memberi $1 \mathrm{~kg}$ kotoran sapi yang telah diencerkan dengan air 1 liter ditambah limbah sayuran sebanyak 250 gr, Perawatan cacing tanah dilakukan dengan mengaduk-aduk media pada saat pemberian pakan.

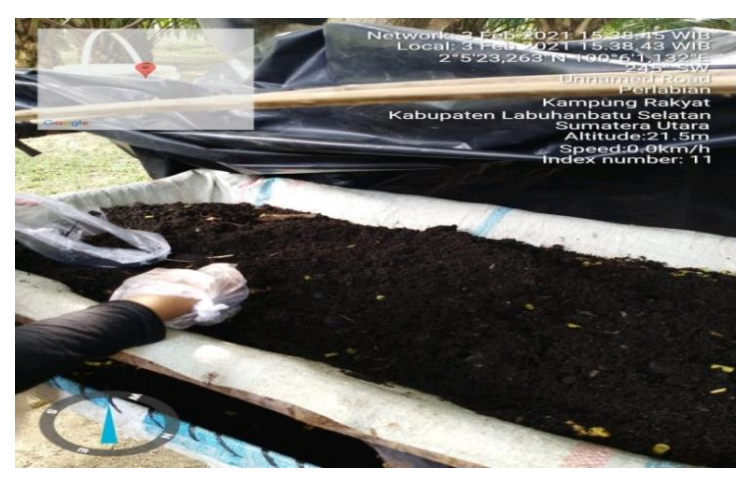

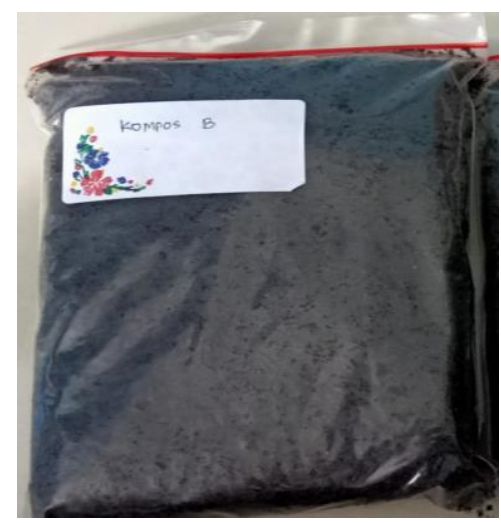

Gambar 1. Pupuk Kascing

Setelah empat minggu, kascing dipanen dengan cara memberikan lampu atau cahaya dipermukaan media,karena cacing sangat sensitif sama cahaya,maka dengan begitu cacing akan naik kepermukaan dan berkumpul sehingga memudahkan untuk memanen cacing tersebut.Selanjutnya cacing diambil menggunakan sarung tangan satu persatu. Kascing lalu dikemas untuk diuji lanjut di laboratorium PT.Socfindo Perbaungan, Kecamatan Teluk Mengkudu dan Sei Rampah, Kabupaten Serdang Bedagai, Sumatera Utara. Data-data yang didapatkan dari penelitian ini dianalisis secara deskriptif dan mengkajinya dari beberapa sumber literatur lainnya. Adapun variabel pengamatan uji kualitas kompos adalah kandungan $\mathrm{N}$, $\mathrm{P}, \mathrm{K}, \mathrm{C}$ organik, $\mathrm{C} / \mathrm{N}$ dan $\mathrm{pH}$.

\section{Hasil Dan Pembahasan}

Berdasarkan hasil analisis kompos yang telah dilakukan, dapat diketahui kandungan unsur hara dari kascing yang dihasilkan. Hasil tersebut disajikan pada Tabel 1 berikut. Hasil tersebut selanjutnya dibandingkan dengan pupuk kompos standart SNI-19-7030-2004.

Tabel 1.Hasil Uji Analisis Kandungan Hara Kascing

\begin{tabular}{cccc}
\hline NO & Parameter & Kascing A & Kriteria \\
\hline 1 & C-C-Org (\%) & 10,55 & Sesuai \\
2 & C-N-K Jehl (\%) & 1,07 & Sesuai \\
3 & C-P-Total (\%) & 0,22 & Sesuai \\
4 & C-K-Total(\%) & 0,30 & Sesuai \\
5 & $\mathrm{pH}$ & 6,5 & Sesuai \\
6 & $\mathrm{C} / \mathrm{N}$ & 9,85 & Sesuai \\
\hline
\end{tabular}

Adapun standart kompos minimum menurut SNI 197030-2004, kompos harus mengandung C Organik sebesar $9,8 \%, \mathrm{~N}$ sebesar $0,40 \%, \mathrm{P}$ sebesar $0,1 \%, \mathrm{~K}$ sebesar $0,20 \%$ dan 
pH 4-9 (Eulis, 2009). Berdasarkan hasil analisis kascing pada penelitian ini dapat diketahui bahwa kandungan unsur hara kascing ini memenuhi standart SNI sebagai kompos. Sehingga dapat diproduksi dan diaplikasikan pada beberapa tanaman untuk mengetahui pengaruhnya pada pertumbuhan dan perkembangan tanaman. Selain itu, kascing ini juga dapat diujicobakan untuk memperbaiki kualitas tanah yang rusak akibat pemupukan dan pada lahan-lahan marginal.

Arif et al., (2007) menyatakan bahwa kualitas kascing yang baik salah satunya ditunjukkan dengan $\mathrm{pH}$ yang normal karena dapat meningkatkan kualitas tanah. Menurut Liptan (2017) selain mempunyai hampir semua unsur-unsur yang dibutuhkan oleh tanaman, kascing juga mengandung unsur makro yang lebih tinggi, dan kascing juga mampu menetralkan pH tanah. Mashur (2001) menyatakan kascing yang berkualitas baik ditandai dengan warna hitam kecoklatan hingga hitam, tidak berbau, bertekstur remah dan matang $(\mathrm{C} / \mathrm{N}<20)$. Yenli (2012) menyatakan bahwa nutrisi kascing dapat menyuburkan tanaman karena kascing memiliki bentuk dan struktur yang mirip dengan tanah, namun ukuran partikel-partikelnya lebih kecil dan lebih kaya akan bahan organik sehingga meningkatkan aerasi media tanam.

Kascing hasil penelitian ini memiliki warna hitam pekat, tidak berbau, dan berbentuk seperti butiran tanah kecil dengan $\mathrm{C} / \mathrm{N}$ sebesar 9,85. Dari kandungan unsur hara, kascing ini memiliki unsur hara makro yang baik, sehingga dapat mendukung ketersediaan unsur hara NPK pada tanah. Pada penelitian ini kandungan $\mathrm{C}$-Org sebesar $10,55 \%$, N sebesar $1,07 \%$, P sebesar $0,22 \%$, K sebesar $0,30 \%, \mathrm{C} / \mathrm{N}$ sebesar 9,85 dan $\mathrm{pH}$ sebesar 6,5. Hasil penelitian ini sejalan dengan kascing dari hasil penelitian Manahan (2016), yang mengandung $\mathrm{N}$ total sebesar $0,26 \%$ kandungan $\mathrm{P}$ tersedia tinggi yaitu $27,18 \%$ dan K total yaitu $0,35 \%$. Atiyeh et al., (2000), menambahkan bahwa unsur hara dalam cacing tergolong lengkap baik hara makro maupun hara mikro, dan tersedia dalam bentuk yang mudah diserap oleh tanaman.

Produk kascing ini diharapkan nantinya mampu mengurangi penggunaan pupuk kimia dan mengurangi pencemaran lingkungan. Hal ini dikarenakan kascing mengandung berbagai bahan yang dibutuhkan untuk pertumbuhan tanaman seperti auksin, sitokinin dan giberellin danmengandung unsur hara $(\mathrm{N}, \mathrm{P}, \mathrm{K}, \mathrm{Mg}$ dan $\mathrm{Ca})$ serta Azotobacter yang merupakan bakteri penambat $\mathrm{N}$ nonsimbiotik yang akan membantu memperkaya unsur $\mathrm{N}$ yang dibutuhkan oleh tanaman (Oka, 2007) .

\section{Kesimpulan}

Kascing memenuhi standart SNI sebagai pupuk kompos dengan kandungan C-Org sebesar 10,55\%, N sebesar 1,07\%, P sebesar $0,22 \%, \mathrm{~K}$ sebesar $0,30 \%, \mathrm{C} / \mathrm{N}$ sebesar $9,85 \mathrm{dan} \mathrm{pH}$ sebesar 6,5.

\section{Daftar Pustaka}

Anif, S, Triastuti R\& Mukhlissual F,2007, Pemanfaatan LImbah Tomat Sebagai Pengganti EM-4 pada proses Pengomposan Sampah Organik,Jurnal Penelitia Sains \& Teknologi, Vol 8 No. 2, hal 128

Arifah S.M, 2013. Aplikasi Penggunaan Pupuk Organik Kompos dan Kascing Terhadap Tanaman Pakcoy. Naskah Publikasi. DP2M. UMM.

Atiyeh, R. M., S. Subler, C.A. Edwards, G. Bachman, J. D. Metzger dan W. Shuster. 2000. Effects of vermicomposts and composts on plant growth in horticultural container media and soil. Journal Pedo biologia, 44, 579-590. Ohio State University. USA.

Badan Pusat Statistik Kabupaten Labuhanbatu. 2016. Kabupaten Labuhanbatu dalam Angka. Medan : CV. Prima Jaya.

Ditjen PPHP. 2006. Pedoman Pengolahan Limbah Industri Kelapa Sawit.Kabupaten Labuhanbatu : Subdit Pengelolaan Lingkungan Direktorat Pengolahan Hasil Pertanian Departemen Kehutanan.

Eulis T. M., 2009. Biokonversi Limbah Industri Peternakan. UNPADPRESS. Bandung.

Febriyantiningrum, K., Nurfitria, N., \& Rahmawati, A. (2018, September). Studi Potensi Limbah Sayuran Pasar Baru Tuban Sebagai Pupuk Organik Cair. In Seminar Nasional Penelitian dan Pengembangan Masyarakat.

Liptan. 2001. Pertanian Organik. Balai Pengkajian Teknologi Pertanian (BPTP). Pekan Baru.

Manahan, S. (2016). Pengaruh Pupuk Npk Dan Kascing Terhadap Pertumbuhan Kelapa Sawit (Elaeis Guineensis Jacq.) Fase Main Nursery (Doctoral dissertation, Riau University).

Mashur.2001. Vermikompos Pupuk Organik Berkualitas dan Ramah Lingkungan. Mataram: Instalasi Penelitian Dan Pengkajian Teknologi Pertanian (Ipptp) Mataram Badan Penelitian.

Muktiani, A., J. Achmadi dan B. I. M. Tampubolon. 2007. Fermentabilitas Rumen Secara In Vitro Terhadap Sampah Sayur Yang Diolah. JPPT., 32 (1) : 44-50.

Oka, A. A. (2012). Pengaruh pemberian pupuk kascing terhadap pertumbuhan tanaman kangkung darat (Ipomea reptans poir). Jurnal Sains MIPA Universitas Lampung, 13(1).

Parnata, A.S. 2010.Meningkatkan Hasil Panen dengan Pupuk Organik Agromedia Pustaka.Jakarta

Saputro, D. D., Wijaya, B. R., \& Wijayanti, Y. (2014). Pengelolaan limbah peternakan sapi untuk meningkatkan kapasitas produksi pada kelompok ternak patra sutera. Rekayasa: Jurnal Penerapan Teknologi dan Pembelajaran, 12(2), 91-98

Yenli. 2012. Pupuk Kascing Organik. Dalamhttp://www.kaskus.co.id/ pupukkascing-organik/.Diakses tanggal 3 Maret 2021 